\title{
End-stage renal failure reduces central clearance and prolongs the elimination half life of remifentanil
}

\author{
[L'insuffisance rénale terminale réduit la clairance centrale et prolonge la \\ demi-vie d'élimination du rémifentanil]
}

Ashraf A. Dahaba MD MSc, ${ }^{*}$ Karl Oettl PhD, $†$ Fedor von Klobucar MD, ${ }^{*}$ Gilbert Reibnegger PhD, $\dagger$ Werner F. List MD*

Purpose: To evaluate the pharmacokinetics of remifentanil in 13 end-stage renal failure patients compared to matched control patients with normal renal function.

Methods: Remifentanil was infused for $20 \mathrm{~min}$ at a rate of 0.1 $\mu \mathrm{g} \cdot \mathrm{kg}^{-1} \cdot \mathrm{min}^{-1}$. Serial arterial blood samples $(3 \mathrm{~mL})$ were drawn at the start of infusion (zero), five, ten, 15, 20, 22.5, 25, 27.5, 30, 35, $40,45,50,55$ and $60 \mathrm{~min}$. Blood samples were immediately preserved with citric acid and chilled on ice. High performance liquid chromatography-tandem mass spectrometry concentration assay was performed using Gl 95779B internal standard.

Results: A two-compartment pharmacokinetic model provided an adequate fit for individual patient data. There was no difference in the mean $\pm \mathrm{SD}$ distribution half life $\left(t_{1 / 2}\right)$ between the renal failure group ( $1.65 \pm 0.7 \mathrm{~min}$ ) and the control group ( $1.58 \pm 0.54 \mathrm{~min})$. There was a significant difference in the central clearance $\left(\mathrm{Cl}_{\mathrm{C}}\right)$ and elimination half life $\left(t_{1 / 2} \beta\right)$ between the renal failure group $(28 \pm 7$ $\mathrm{mL} \cdot \mathrm{kg}^{-1} \cdot \mathrm{min}^{-1}$ and $18.86 \pm 2.06 \mathrm{~min}$, respectively) and the control group $\left(46.3 \pm 13.8 \mathrm{~mL} \cdot \mathrm{kg}^{-1} \cdot \mathrm{min}^{-1}\right.$ and $16.35 \pm 2.99 \mathrm{~min}$, respectively). Remifentanil blood concentrations were significantly higher in the renal failure group than in the control group.

Conclusion: We have demonstrated a significant reduction in the $\mathrm{Cl}_{\mathrm{c}}$ and a prolongation of $\mathrm{t}_{1 / 2}$ B of remifentanil in end-stage renal failure patients. While statistically significant, these variations in the pharmacokinetics of remifentanil were clinically modest and may be explained by a reduced volume of distribution in the period following hemodialysis.
Méthode : Le rémifentanil a été perfusé pendant 20 min à 0,1 $\mu \mathrm{g} \cdot \mathrm{kg}^{-1} \cdot \mathrm{min}^{-1}$. Une série d'échantillons de sang artériel $(3 \mathrm{~mL})$ a été prélevée au début de la perfusion (zéro), puis à cinq, dix, 15, 20, $22,5,25,27,5,30,35,40,45,50,55$ et $60 \mathrm{~min}$. Le sang a été préservé avec de l'acide citrique et conservé sur de la glace. Une analyse des concentrations par chromatographie liquide haute performance et spectrométrie de masse en tandem a été réalisée en utilisant un étalon interne Gl 95779B.

Résultats : Un modèle pharmacocinétique à deux compartiments a fourni un ajustement adéquat des données de chaque patient. II n'y a pas eu de différence de demi-vie de distribution moyenne \pm l'écart type $\left(t_{1 / 2} \alpha\right)$ entre les patients atteints d'insuffisance renale $(1,65 \pm$ $0,7 \mathrm{~min}$ ) et les patients témoins ( $, 58 \pm 0,54 \mathrm{~min})$. II y a eu une différence significative de clairance centrale $\left(\mathrm{Cl}_{\mathrm{C}}\right)$ et de demi-vie d'élimination $\left(t_{1 / 2} \beta\right)$ entre le groupe d'insuffisance rénale (28 \pm 7 $\mathrm{mL} \cdot \mathrm{kg}^{-1} \cdot \mathrm{min}^{-1}$ et $18,86 \pm 2,06 \mathrm{~min}$, respectivement) et le groupe témoin $\left(46,3 \pm 13,8 \mathrm{~mL} \cdot \mathrm{kg}^{-1} \cdot \mathrm{min}^{-1}\right.$ et 16,35 $\pm 2,99 \mathrm{~min}$, respectivement). Les concentrations sanguines de rémifentanil ont été significativement plus élevées chez les patients atteints d'insuffisance rénale.

Conclusion : Nous avons démontré une réduction significative de la $\mathrm{Cl}_{c}$ et une prolongation de $t_{1 / 2}$ B du rémifentanil chez des patients atteints d'insuffisance rénale terminale. Quoique statistiquement significatives, ces variations de la pharmacocinétique du rémifentanil sont cliniquement faibles et peuvent s'expliquer par la réduction du volume de distribution qui suit l'hémodialyse.

Objectif : Évaluer la pharmacocinétique du rémifentanil chez 13 patients présentant une insuffisance rénale terminale, comparés à des témoins appariés dont la fonction rénale est normale.

From the Departments of Anaesthesiology and Intensive Care Medicine, ${ }^{\star}$ and Medical Chemistry and Pregl Laboratory, $\dagger$ Karl-Franzens University, Graz, Austria.

Address correspondence to: Dr. Ashraf Dahaba, Department of Anaesthesiology and Intensive Care Medicine, Karl-Franzens University, Auenbruggerplatz 29, A-8036, Graz, Austria. Phone: ++ 43-316-385-2829; Fax: ++ 43-316-385-3267;

E-mail: Ashraf.Dahaba@kfunigraz.ac.at

Accepted for publication November 13, 2001.

Revision accepted January 18, 2002. 
$\mathrm{P}$ ATIENTS with end-stage renal failure require anesthesia for various surgical procedures from vascular access for hemodialysis to kidney transplantation. An opioid, which is independent of renal metabolism, would be valuable in such a case. Remifentanil hydrochloride is a potent ultra-short-acting $\mu$ receptor agonist. Its methyl propionic acid ester side chain makes it highly susceptible to rapid hydrolysis by nonspecific naturally present plasma and tissue esterases. ${ }^{1}$

End-stage renal failure patients manifest fluid volume depletion following recent hemodialysis. ${ }^{2}$ However, their impaired compensatory responses, ${ }^{3}$ the associated biochemical and physiological disturbances such as renin- angiotensin disorders, ${ }^{4}$ in addition to the long-term antihypertensive therapies result in a reduced ability to regulate fluid volume status, and hence might modify the distribution, elimination and clearance of remifentanil. The purpose of this study was to evaluate the pharmacokinetics of remifentanil in 13 end-stage renal failure patients compared to matched control patients with normal renal function.

\section{Patients and methods \\ Study design}

A prospective controlled clinical consecutive study was conducted in conformity with the guidelines of the "consolidated standards of reporting trials $(\mathrm{CON}$ SORT)-statement". ${ }^{5}$ We considered remifentanil elimination half life $\left(t_{1 / 2} \beta\right)$ as the primary clinical variable upon which a priori power analysis for $t$ test was performed. Based upon previously reported data, ${ }^{6}$ an assumed $t_{1 / 2} \beta$ of nine minutes revealed that a group size of 13 would be required to detect a two- minute difference between the two groups with $>0.8$ power. After approval of our Institutional Ethics Committee, all patients who agreed to participate in the study gave a written informed consent. We excluded potential participants with a known hypersensitivity to opioids or with $20 \%$ deviation from ideal body weight. None of the female participants were pregnant or breast feeding. Recruitment was three to four patients per week in the period from May 72001 until June 282001.

Thirteen end-stage renal failure patients, undergoing the creation of end-to-side arterio-venous fistulas or insertion of a prosthetic arterio-venous graft were included in the study. Each end-stage renal failure patient was matched for gender, age and body weight with an ASA I-II patient with normal renal function who was undergoing an elective surgical procedure expected to last $1-1.5 \mathrm{hr}$. All patients had preoperative measurements of creatinine clearance, serum creati- nine, urea, hemoglobin and potassium concentrations. Patients in the renal failure group had undergone hemodialysis within $24 \mathrm{hr}$ prior to surgery and were receiving human recombinant erythropoietin therapy.

\section{Anesthesia protocol}

Patients were premedicated with 5-10 mg midazolam orally one hour before the operation. Anesthesia was induced with $2-3 \mathrm{mg} \cdot \mathrm{kg}^{-1}$ propofol until the eyelash reflex was obtunded. Remifentanil was infused for 20 $\min { }^{6}{ }^{6}$ at a clinically relevant rate of $0.1 \mu \mathrm{g} \cdot \mathrm{kg}^{-1} \cdot \mathrm{min}^{-1}$. Following termination of the remifentanil infusion, analgesia was maintained with 50-100 $\mu \mathrm{g}$ fentanyl supplements. The trachea was intubated following 0.6 $\mathrm{mg} \cdot \mathrm{kg}^{-1}$ rocuronium administration. Anesthesia was maintained with $60 \%$ nitrous oxide in oxygen and $0.1-0.15 \mathrm{mg} \cdot \mathrm{kg}^{-1} \cdot \mathrm{min}^{-1}$ propofol infusion. Ringer's lactate solution was infused in the control patients, and potassium-free Ringer's acetate was infused in the renal failure patients to replace fluid loss.

\section{Blood sample acquisition, handling and processing}

Serial arterial blood samples $(3 \mathrm{~mL})$ were drawn at the start of infusion (zero), five, ten, 15, 20, 22.5, 25, 27.5, $30,35,40,45,50,55$ and $60 \mathrm{~min}$. Blood samples were immediately preserved by the addition of $50 \mu \mathrm{L}$ of $50 \%$ citric acid then chilled on ice.

\section{Remifentanil concentration assay}

After all samples were collected, a modified Selinger et $a l^{7}$ method was used for the extraction. The samples were denaturated by the addition of $1 \mathrm{~mL}$ of $1 \mathrm{~mol} \cdot \mathrm{L}^{-1}$ phosphate buffer $(\mathrm{pH} 7.4)$ and $5 \mathrm{~mL} \mathrm{n}$-butyl chloride to $1 \mathrm{~mL}$ of blood. One hundred $\mu \mathrm{L}\left(50 \mu \mathrm{g} \cdot \mathrm{L}^{-1}\right.$ in acetonitrile) of the internal standard GI 95779B (GlaxoSmithKline, Middlesex, UK) were added. The tubes were then roto-mixed for ten minutes, centrifuged at $1800 \mathrm{~g}$ at $4^{\circ} \mathrm{C}$ for another ten minutes. The organic layer was transferred into a conical tube and the solvent evaporated under nitrogen at $37^{\circ} \mathrm{C}$. The residual was dissolved in $150 \mu \mathrm{L}$ of acetonitrile.

Blood samples were analyzed in duplicate. Fifty $\mu \mathrm{L}$ of the samples were injected into a high performance liquid chromatograph (Spectronex, Vienna, Austria). Separation was conducted using a $200 \times 3 \mathrm{~mm}$ column filled with cyanopropyl silica (prontosil 120-3$\mathrm{CN}$ particles) and $10 \mathrm{mM}$ ammonium acetate with $1 \%$ acetic acid in 30\% acetonitrile as solvent. The system was coupled with an ion trap mass spectrometer (Finnigan, San Jose, USA) equipped with an atmospheric pressure chemical ionisation ion source in the tandem mass spectrometer mode. The mother ions for remifentanil $\left(377.2 \mathrm{~m} \mathrm{z}^{-1}\right)$ and the internal standard 
TABLE I Patient demographics and preoperative blood investigations

\begin{tabular}{|c|c|c|c|}
\hline & $\begin{array}{l}\text { Control } \\
\text { group }\end{array}$ & $\begin{array}{l}\text { Renal failure } \\
\text { group }\end{array}$ & P value \\
\hline Male/female & $7 / 6$ & $7 / 6$ & \\
\hline Age (yr) & $58.2 \pm 11.5$ & $60.5 \pm 7.7$ & 0.632 \\
\hline Weight (kg) & $69 \pm 18.4$ & $72.8 \pm 12.8$ & 0.515 \\
\hline $\mathrm{Cr}\left(\mu \mathrm{mol} \cdot \mathrm{L}^{-1}\right)$ & $93.9 \pm 11.2$ & $494.1 \pm 99.3$ & 0.001 \\
\hline $\mathrm{Cl}_{\mathrm{cr}}\left(\mathrm{mL} \cdot \min ^{-1} \cdot 1.73 \mathrm{~m}^{-2}\right)$ & $75.1 \pm 9$ & $9.5 \pm 3.9$ & 0.011 \\
\hline Urea $\left(\mathrm{mmol} \cdot \mathrm{L}^{-1}\right)$ & $5.8 \pm 2.3$ & $16.1 \pm 4.4$ & 0.014 \\
\hline $\mathrm{Hb}\left(\mathrm{g} \cdot \mathrm{dL}^{-1}\right)$ & $15.1 \pm 0.8$ & $10.4 \pm 0.9$ & 0.0001 \\
\hline $\mathrm{K}^{+}\left(\mathrm{mmol} \cdot \mathrm{L}^{-1}\right)$ & $4 \pm 0.1$ & $4.4 \pm 0.9$ & 0.534 \\
\hline
\end{tabular}

Mean $\pm \mathrm{SD} ; n=13 ; \mathrm{Cr}=$ creatinine $; \mathrm{Cl}_{\mathrm{cr}}=$ creatinine clearance; $\mathrm{Hb}=$ hemoglobin; $\mathrm{K}^{+}=$potassium.

$\left(391.2 \mathrm{~m} \mathrm{z}^{-1}\right)$ were isolated and fragmented with collision energy of $15 \%$. For quantification, the ratio of peak areas remifentanil/internal standard were taken from the chromatogram of the almost exclusive remifentanil daughter ion $\left(344.9 \mathrm{~m} \mathrm{z}^{-1}\right)$ and that of the internal standard $\left(358.9 \mathrm{~m} \mathrm{z}^{-1}\right)$. The internal standard levels were used to rectify any variations in recovery and stability among samples. Two sets of calibration curves for quantification were constructed using blank blood spiked with remifentanil $(0.5,1,2$, 5 and $\left.10 \mu \mathrm{g} \cdot \mathrm{L}^{-1}\right)$ and internal standard $\left(50 \mu \mathrm{g} \cdot \mathrm{L}^{-1}\right)$ with a lower quantification limit of $0.1 \mu \mathrm{g} \cdot \mathrm{L}^{-1}$.

\section{Pharmacokinetic analysis}

The pharmacokinetic analysis was performed using the SCIENTIST® program (MicroMath Scientific Software Inc., Salt Lake City, Utah, USA). Data analysis involved fitting the remifentanil blood concentration time profile of individual patients to non-compartmental as well as multi-compartmental pharmacokinetic models.

\section{Moment analysis}

A classic non-parametric moment analysis was applied to calculate the model independent pharmacokinetic parameters. The area under the concentration $v$ s time curve (AUC) was calculated by the linear trapezoidal method. Mean residence time (MRT) is equivalent to a time constant for a single compartment model and indicates the time taken for $63.2 \%$ of a remifentanil dose to leave the body (Appendix).

\section{Non-linear mixed effects model compartmental analysis} The parametric non-linear mixed effects model compartmental goodness of fit analysis for individual patients was performed. The model comprised central
TABLE II Pharmacokinetic variables

\begin{tabular}{|c|c|c|c|}
\hline & $\begin{array}{l}\text { Control } \\
\text { group }\end{array}$ & $\begin{array}{l}\text { Renal failure } \\
\text { group }\end{array}$ & P value \\
\hline \multicolumn{4}{|l|}{ Moment analysis } \\
\hline $\operatorname{AUC}\left(\mu \mathrm{g} \cdot \mathrm{min}^{-1} \cdot \mathrm{L}^{-1}\right)$ & $46.2 \pm 11.9$ & $75.9 \pm 21.4$ & 0.009 \\
\hline $\operatorname{MRT}(\min )$ & $11.6 \pm 5.01$ & $11.92 \pm 3.18$ & 0.895 \\
\hline $\mathrm{Vd}_{\mathrm{ss}}\left(\mathrm{mL} \cdot \mathrm{kg}^{-1}\right)$ & $566.4 \pm 116.3$ & $358 \pm 57.7$ & 0.002 \\
\hline $\mathrm{Cl}\left(\mathrm{mL} \cdot \mathrm{kg}^{-1} \cdot \mathrm{min}^{-1}\right)$ & $48.7 \pm 14.6$ & $29.9 \pm 7.8$ & 0.017 \\
\hline \multicolumn{4}{|c|}{ Non-linear mixed effects model compartmental analysis } \\
\hline \multicolumn{4}{|c|}{ Micro rate constants $\left(\mathrm{min}^{-1}\right)$} \\
\hline $\mathrm{K}_{10}$ & $0.32 \pm 0.17$ & $0.29 \pm 0.14$ & 0.697 \\
\hline $\mathrm{K}_{12}$ & $0.15 \pm 0.05$ & $0.19 \pm 0.11$ & 0.357 \\
\hline $\mathrm{K}_{21}$ & $0.07 \pm 0.02$ & $0.07 \pm 0.02$ & 0.884 \\
\hline \multicolumn{4}{|c|}{ Apparent volumes of distribution $\left(m L \cdot \mathrm{kg}^{-1}\right)$} \\
\hline $\mathrm{V}_{1}$ & $176.5 \pm 33.4$ & $118.3 \pm 27.1$ & 0.006 \\
\hline$v_{2}$ & $392.3 \pm 99.2$ & $291.5 \pm 59.1$ & 0.045 \\
\hline $\mathrm{Vd}_{\mathrm{ss}}$ & $568.9 \pm 118$ & $410 \pm 83.6$ & 0.019 \\
\hline \multicolumn{4}{|c|}{ Central clearance $\left(m L \cdot \mathrm{kg}^{-1} \cdot \mathrm{min}^{-1}\right)$} \\
\hline $\mathrm{Cl}_{\mathrm{c}}$ & $46.3 \pm 13.8$ & $28 \pm 7$ & 0.014 \\
\hline \multicolumn{4}{|c|}{ Fractional coefficients $\left(\mu g \cdot L^{-1}\right)$} \\
\hline A & $14.48 \pm 9.29$ & $19.55 \pm 8.49$ & 0.307 \\
\hline $\mathrm{B}$ & $0.79 \pm 0.37$ & $1.35 \pm 0.36$ & 0.019 \\
\hline \multicolumn{4}{|c|}{ Hybrid rate constants $\left(\mathrm{min}^{-1}\right)$} \\
\hline$\alpha$ & $0.49 \pm 0.19$ & $0.5 \pm 0.25$ & 0.927 \\
\hline$B$ & $0.04 \pm 0.01$ & $0.03 \pm 0.01$ & 0.643 \\
\hline \multicolumn{4}{|l|}{ Half lives (min) } \\
\hline$t_{1 / 2} \alpha$ & $1.58 \pm 0.54$ & $1.65 \pm 0.7$ & 0.856 \\
\hline $\mathrm{t}_{1 / 2} \beta$ & $16.35 \pm 2.99$ & $18.86 \pm 2.06$ & 0.045 \\
\hline
\end{tabular}

Mean \pm SD; $n=13 ;$ AUC $=$ blood remifentanil concentration $v s$ time area under the curve; $\mathrm{MRT}=$ mean residence time; $\mathrm{Vd}_{\mathrm{ss}}=$ apparent volume of distribution at steady state; $\mathrm{Cl}=$ clearance; $\mathrm{K}_{10}$ = elimination rate constant; $\mathrm{K}_{12}, \mathrm{~K}_{21}=$ inter-compartment rate constants; $\mathrm{V}_{1}=$ central volume of distribution; $\mathrm{V}_{2}=$ peripheral volume of distribution; $\mathrm{Cl}_{\mathrm{c}}=$ central clearance; $\alpha, \mathrm{B}^{2}=$ hybrid rate constants; $t_{1 / 2} \alpha=$ distribution half life; $t_{1 / 2} \beta=$ elimination half life.

and peripheral compartments with exit and input into the central compartment, and elimination only from the central compartment. Alpha and $B$ indicate the hybrid rate constants, since each comprises elements of distribution as well as elimination (Appendix).

\section{Statistical analysis}

As our data displayed a normal distribution, the $t$ test for difference between means was used for data analysis. Repeated measures analysis of variance (ANOVA) was used for remifentanil blood concentrations group comparison. Data were expressed as mean \pm SD. $P<0.05$ was considered statistically significant.

\section{Results}

The two groups were comparable with respect to body weight at the day of surgery and age. Blood investigations in the renal failure group were typical of patients undergoing regular hemodialysis (Table I). 


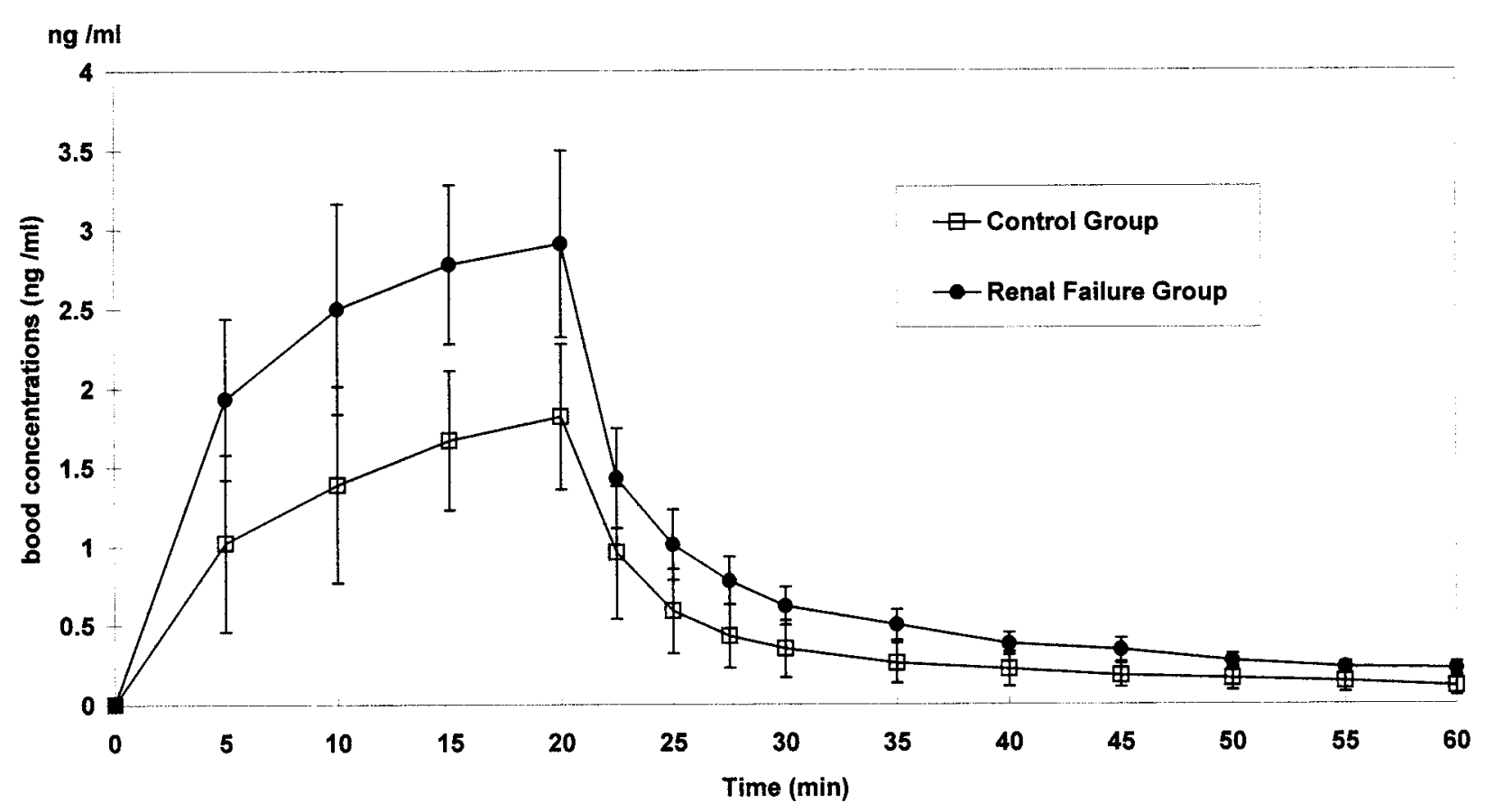

FIGURE Remifentanil blood concentrations $p$ s time decay curve. Mean $\pm \mathrm{SD} ; n=13$. Remifentanil blood concentrations were significantly higher in the renal failure group than in the control group (repeated measures ANOVA, $P<0.05$ ).

In the blood concentration vs time decay curve, remifentanil concentrations were significantly higher in the renal failure group compared to the control group (Figure).

\section{Moment analysis}

There was no difference in the MRT between the two groups. The AUC was higher, while the volume of distribution at steady state $\left(\mathrm{Vd}_{\mathrm{ss}}\right)$ and clearance $(\mathrm{Cl})$ were reduced in the renal failure group compared to the control group (Table II).

Non-linear mixed effects model compartmental analysis There was no difference in the exit, inter-compartment rate constants or distribution half life $\left(t_{1 / 2} \alpha\right)$ between the two groups. The volumes of distribution and central clearance $\left(\mathrm{Cl}_{c}\right)$ were reduced, while $t_{1 / 2} \beta$ was prolonged, in the renal failure group compared to the control group (Table II).

\section{Discussion}

\section{Moment analysis}

Our results of a classic moment analysis in patients with normal renal function $\left(\mathrm{Cl}\right.$ of $3.3 \mathrm{~L} \cdot \mathrm{min}^{-1}$, MRT of $11.6 \mathrm{~min}$, and $\mathrm{V}_{\mathrm{ss}}$ of $37.6 \mathrm{~L}$ ) are in accordance with previous model-independent studies. Remifentanil $\mathrm{Cl}$ of $2.9 \mathrm{~L} \cdot \mathrm{min}^{-1}$, MRT of $10.9 \mathrm{~min}$, and $\mathrm{Vdd}_{\mathrm{ss}}$ of $31.8 \mathrm{~L}$ were reported in two studies. ${ }^{6,8}$ Three $\mathrm{L} \cdot \mathrm{min}^{-1} \mathrm{Cl}$, eight minutes MRT and $24.1 \mathrm{~L}$ $\mathrm{Vd}_{\mathrm{ss}}$ were reported in a third study. ${ }^{9}$

Non-linear mixed effects model compartmental analysis In our study, compartmental statistical analysis of the goodness of fit demonstrated that a two-compartment model provided an adequate fit for individual patient data. This is consistent with a central compartment comprising blood and rapidly perfused tissues through which remifentanil distributes rapidly and a peripheral compartment comprising adipose and other, less perfused, tissues through which remifentanil distributes more slowly.

Our study revealed that remifentanil blood concentration $v s$ time decay was bi-exponential as blood concentrations leveled out at the lower quantification limit of the assay $\left(0.1 \mu \mathrm{g} \cdot \mathrm{L}^{-1}\right)$ near the end of the 60 min sampling period. This implies that distribution to a much smaller third compartment, below the lower sensitivity limit of our assay could still be present. 
Since our study was designed to evaluate remifentanil pharmacokinetics in clinically relevant infusion rates, this did not allow us to demonstrate if a tri-exponential decay to a smaller third compartment would exist with much higher infusion rates. The elimination characteristics of remifentanil were previously described by bi-exponential, ${ }^{10}$ or tri-exponential, ${ }^{6,8,9}$ rates of decline, reflecting elimination from two or three compartments respectively. A two-compartment model was reported to describe remifentanil kinetics accurately for the first postinfusion hour. ${ }^{6}$ The distribution of remifentanil into a third compartment, with much higher doses, was quite limited and accounted for less than $5 \%$ of the total exposure. ${ }^{6}$

The results of the present study in patients with normal renal function $\left(\mathrm{Cl}_{\mathrm{c}}\right.$ of $3.2 \mathrm{~L} \cdot \mathrm{min}^{-1}, \mathrm{t}_{1 / 2} \alpha$ of 1.6 $\mathrm{min}$, and $\mathrm{a} \mathrm{Vd}_{\mathrm{ss}}$ of $38.1 \mathrm{~L}$ ) were comparable to previous multi-compartment analysis studies, in which remifentanil $\mathrm{Cl}_{\mathrm{c}}$ of $2.8-2.9 \mathrm{~L} \cdot \mathrm{min}^{-1}, \mathrm{t}_{1 / 2} \alpha$ of $0.9 \mathrm{~min}$, and $\mathrm{Vd}_{\mathrm{ss}}$ of $2 \mathrm{l} .8-32.8 \mathrm{~L}$ were reported. 6 ,

\section{End-stage renal failure}

Using a one-compartment model for data analysis, Hoke et al. ${ }^{11}$ reported no significant difference between remifentanil pharmacokinetics in healthy volunteers and those with renal disease. This is in contrast to our results, which clearly demonstrate that remifentanil exhibited a bi-exponential decay in patients of both groups. Data analysis based only on a one-compartment model would not be adequate in such a case.

Our results show a significant alteration in remifentanil pharmacokinetics in end-stage renal failure. This cannot be explained only by degradation, since remifentanil metabolism is esterase based which, probably, makes its degradation independent of renal function. However, the role of the kidney cannot be totally excluded since the elimination of the principal metabolite of remifentanil GI 90291, which possesses 1/300-1/1000 the potency of the parent compound, ${ }^{8}$ has been reported to be markedly reduced in renal failure. ${ }^{11}$

A possible explanation is that end-stage renal failure patients manifest fluid volume depletion following recent dialysis. ${ }^{2}$ In addition, the numerous biochemical and physiological disturbances associated with endstage renal failure result in a reduced ability to regulate fluid volume status. ${ }^{4}$ This was evidenced by the reduced volumes of distribution in renal failure patients. Since dosing of remifentanil was based on the patients' body weight on the day of surgery, this would result in a higher remifentanil blood concentration in the hypovolemic end-stage renal failure patients when compared to the matched-for-weight control patients. This would consequently reduce $\mathrm{Cl}_{c}$ and prolong $\mathrm{t}_{1 / 2} ß$.
In our study, the $\mathrm{Vd}_{\mathrm{ss}}$ in the renal failure group (358 $\left.\pm 57.7 \mathrm{~mL} \cdot \mathrm{kg}^{-1}\right)$ was significantly lower than that of the control group $\left(566.4 \pm 116.3 \mathrm{~mL} \cdot \mathrm{kg}^{-1}\right)$. Conversely, Hoke $e t a l .{ }^{11}$ reported a higher volume of distribution in volunteers with renal failure $\left(229 \mathrm{~mL} \cdot \mathrm{kg}^{-1}\right)$ compared to healthy volunteers $\left(191 \mathrm{~mL} \cdot \mathrm{kg}^{-1}\right)$, which they attributed to the patients becoming hypervolemic between hemodialysis treatments. However, this did not result in a significant difference in the pharmacokinetic parameters reported. One of the differences between their study and ours may be that remifentanil was infused on the day before their study patients' next scheduled hemodialysis. This was not the case in our study where patients, by study design, underwent hemodialysis on the day prior to surgery. We believe this is more in line with common anesthesia practice in patients with end-stage renal failure undergoing elective surgery. Thus, volume status of these patients may have differed between the two studies, explaining (in part at least) the different results. Another difference is the smaller number of patients in Hoke et al.'s study ${ }^{11}(n=8)$ compared to ours $(n=13$, the number required to detect a significant difference between the two groups with $>0.8$ power). In addition, the infusion rates used in the Hoke et al. ${ }^{11}$ trial $\left(0.025-0.05 \mu \mathrm{g} \cdot \mathrm{kg}^{-1} \cdot \mathrm{min}^{-1}\right)$ were lower than the clinically relevant doses that would be used during general anesthesia for end-stage renal failure patients.

It should be noted that an alteration of remifentanil pharmacokinetics in end-stage renal failure does not necessarily reflect a clinically significant prolongation of therapeutic effect. The pharmacodynamic recovery parameters, following a clinically relevant remifentanil infusion, as we have shown in a previous study, ${ }^{12}$ were not significantly prolonged in end-stage renal failure patients compared to patients with normal renal function.

In conclusion, we have demonstrated a significant reduction in the $\mathrm{Cl}_{c}$ and a prolongation of $t_{1 / 2} \beta$ of remifentanil in end-stage renal failure patients. While statistically significant, these variations in the pharmacokinetics of remifentanil were clinically modest and may be explained by a reduced volume of distribution in the period following hemodialysis.

\section{Acknowledgement}

The authors would like to thank Elisabeth Koppe, Department of Medical Chemistry and Pregl Laboratory, Karl Franzens University, for her meticulous work in remifentanil processing and concentration assays. Her great efforts were indeed a valuable contribution to the study. 
APPENDIX Pharmacokinetic variables and calculations Moment analysis

AUC $=$ area under the concentration $v s$ time curve

$\mathrm{Cl}=$ clearance

$\mathrm{Cl}=$ dose $/ \mathrm{AUC}$

$\mathrm{MRT}=$ mean residence time

$\mathrm{Vd}_{\mathrm{ss}}=$ apparent volume of distribution at steady state

$\mathrm{Vd}_{\mathrm{ss}}=\mathrm{Cl} \times \mathrm{MRT}$

Non-linear mixed effects model compartmental analysis

$\mathrm{K}_{10}=$ central compartment elimination rate constant

$\mathrm{K}_{12}=$ central to peripheral compartment rate constant

$\mathrm{K}_{21}=$ peripheral to central compartment rate constant

$\mathrm{V}_{1}=$ central volume of distribution

$\mathrm{V}_{2}=$ peripheral volume of distribution

$\mathrm{Cl}_{\mathrm{c}}=$ central clearance

$\mathrm{Cl}_{\mathrm{c}}=\mathrm{K}_{10} \times \mathrm{V}_{1}$

$\mathrm{A}=$ concentration intercept at time zero of the distribution phase

$\alpha=$ distribution rate constant

$\mathrm{t}_{1 / 2} \alpha=$ distribution half life

$\mathrm{B}=$ concentration intercept at time zero of the elimination phase

$B=$ elimination rate constant

$\mathrm{t}_{1 / 2} \beta=$ elimination half life

\section{References}

1 Bürkle H, Dunbar S, Van Aken H. Remifentanil: a novel, short-acting, $\mu$-opioid. Anesth Analg 1996; 83: 646-51.

2 Henderson LW. Symptomatic hypotension during hemodialysis. Kidney Int 1980; 17: 571-6.

3 Lazarus JM, Hampers CL, Lowrie EG, Merrill JP. Baroreceptor activity in normotensive and hypertensive uremic patients. Circulation 1973; 47: 1015-21.

4 Bailey JL, Mitch WE. Pathophysiology of uremia. In: Brenner BM (Ed.) The Kidney, 6th ed. Philadelphia: WB Saunders Company, 2000: 2059-78.

5 Moher D, Schulz KF, Altman DG, for the CONSORT group. The CONSORT statement: revised recommendations for improving the quality of reports of parallelgroup randomised trials. Lancet 2001; 357: 1191-4.

6 Egan TD, Lemmens HJM, Fiset P, et al. The pharmacokinetics of the new short-acting opioid remifentanil (GI87084B) in healthy adult male volunteers. Anesthesiology 1993; 79: 881-92.

7 Selinger K, Lanzo C, Sekut A. Determination of remifentanil in human and dog blood by HPLC with UV detection. J Pharm Biomed Anal 1994; 12: 243-8.

8 Westmoreland CL, Hoke JF, Sebel PS, Hug CC Jr, Muir KT. Pharmacokinetics of remifentanil (GI87084B) and its major metabolite (GI90291) in patients undergoing elective inpatient surgery. Anesthesiology 1993; 79: 893-903.

9 Egan TD, Minto CF, Hermann DJ, Barr J, Muir KT, Shafer SL. Remifentanil versus alfentanil. Comparative pharmacokinetics and pharmacodynamics in healthy adult male volunteers. Anesthesiology 1996; 84: 821-33.

10 Glass PSA, Hardman D, Kamiyama $\Upsilon$, et al. Preliminary pharmacokinetics and pharmacodynamics of an ultra-short-acting opioid: remifentanil (GI87084B). Anesth Analg 1993; 77: 1031-40.

11 Hoke JF, Shlugman D, Dershwitz M, et al. Pharmacokinetics and pharmacodynamics of remifentanil in persons with renal failure compared with healthy volunteers. Anesthesiology 1997; 87: 533-41.

12 Dahaba AA, von Klobucar F, Rehak PH, List WF. Total intravenous anesthesia with remifentanil, propofol and cisatracurium in end-stage renal failure. Can J Anesth 1999; 46: 696-700. 